\title{
THE INFLUENCE OF MOTHER'S PERCEPTION AND ATTITUDE TOWARD FISH PURCHASING BEHAVIOR IN PEKALONGAN FAMILIES
}

\author{
Ima Audina Safitri*)1, Istiqlaliyah Muflikhati* \\ *Department of Family and Consumer Sciences, Faculty of Human Ecology, \\ Bogor Agricultural University \\ ${ }^{1}$ Corresponding author: imaaudina22@gmail.com
}

\begin{abstract}
This study aims to analyze the influence of perceptions and attitudes on fish purchasing behavior in rural and urban areas. This research used crosssectional study design and took place in Kandang Panjang Village, Pekalongan City as the urban area and Duwet Village, Pekalongan Regency as the rural area. The sample in this study was 100 mothers. Data was analyzed using descriptive test, Independent sample t-test, Pearson correlation test, and multiple linear regression tests. Mother's perception and attitude in urban area were higher than in rural area. In addition, there were significant differences on fish expenditure with urban area was higher than rural area. Regression test showed that perception, location, and mother's age had a significant influence on fish purchasing behaviour.
\end{abstract}

Keywords: attitude, perception, purchasing behavior, rural and urban areas

\begin{abstract}
Abstrak. Penelitian ini bertujuan untuk menganalisis pengaruh persepsi dan sikap ibu terhadap perilaku pembelian ikan di perdesaan dan perkotaan. Penelitian ini menggunakan desain cross sectional study. Penelitian ini dilakukan di Kelurahan Kandang Panjang, Kota Pekalongan sebagai wilayah perkotaan dan Desa Duwet, Kabupaten Pekalongan sebagai wilayah perdesaan. Contoh dalam penelitian ini adalah $100 \mathrm{ibu}$. Data dianalisis menggunakan uji deskriptif, uji beda Independent sample T-test, uji korelasi Pearson, dan uji regresi linier berganda. Pesepsi dan sikap ibu terhadap ikan lebih tinggi di perkotaan dibandingkan perdesaan. Selain itu, terdapat perbedaan yang signifikan pada pengeluaran untuk ikan, pengeluaran untuk ikan di perkotaan lebih tinggi dibandingkan perdesaan. Hasil uji regresi menunjukkan bahwa persepsi, lokasi, dan usia ibu berpengaruh signifikan terhadap perilaku pembelian ikan.
\end{abstract}

Kata kunci: perdesaan, perkotaan, perilaku pembelian, persepsi, sikap 


\section{Introduction}

Indonesia is a maritime country that has a potential of abundant marine products. In addition to sea fish, there are also abundant freshwater fish in Indonesia. Fish habitat determines the nutrient content of the fish. Freshwater fish are known to have high contents carbohydrates and protein, while sea fish are known to have high contents of fats, vitamins, and minerals. Both sea fish and freshwater fish have a good nutritional content for the body. The culture of eating sea fish that is high in Japanese society proves the increasing quality of health and intelligence of children in Japan. Regular consumption of fish can reduce the risk of chronic diseases including cardiovascular (Verbeke \& Vackier, 2004).

Indonesia has a great opportunity in making fish as the main commodity that can be consumed by the community. However, the consumption level of the fish population in Indonesia is still low; this can be seen from the data of Indonesian consumption level in 2015 only reach $41.11 \mathrm{~kg} / \mathrm{cap} / \mathrm{year}$ while the provision of per capita fish reaches $51.80 \mathrm{~kg} / \mathrm{cap} / \mathrm{year}$ (Jannah, 2015). Other Asian countries have higher fish consumption levels such as Japan $140 \mathrm{~kg} / \mathrm{cap} / \mathrm{year}$ and Malaysia $70 \mathrm{~kg} / \mathrm{cap} / y e a r$. The low level of fish consumption in Indonesia is not comparable with the marine and ponds area owned by Indonesia.

There are two factors that can influence the purchasing behaviour of fish, namely internal and external factors. Internal factors are factors that exist within the consumer or commonly called the psychological factors. According to Khaniwale (2015), some psychological factors that can influence behavior are perceptions and attitudes. External factors that may influence are environmental factors or the availability of fish in the region and social factors such as myth (Nurjannah et al., 2015). The availability of family food is still determined by the mother or mother's substitute (Waysima et al., 2011).

Consumers for the first time feel the product when will buy or consume products. Price perception is important for consumers to buy organic food (Sangkumchaliang \& Huang, 2012). The results of a survey conducted by Badr (2015), consumer perceptions about barriers in consuming freshwater fish are flavour, bone, and smell. Gills and eyes are also noticed by consumers when buying (Masoom et al., 2015).

In addition to perception, psychological factors that can affect behaviour is an attitude. Attitude is the expression of consumer feeling about an object whether liked or not, and attitudes can also describe consumer confidence in the various attributes and benefits of the object (Sumarwan, 2011). Indriana and Widajanti (2005) indicate that the relationship between income and availability of fish at household are significantly related. Price and location are two factors that can influence consumer attitudes (Alibabic et al., 2011).

The value of a product for an individual depends on the individual's perceptions and how attitudes toward the product influence product purchase. Individuals who receiving the same stimulus will select, organize, and interpret stimulus differently depending on consumer needs, values, and expectations (Sumarwan et al., 2012). Perceptions and attitudes can affect the buying behaviour of products (Khaniwale, 2015). Consumer confidence in negative products and experiences will have a negative impact on future purchases (Jafaar et al., 2012). 
High or low the fish consumption is influenced by the availability of fish in the region and the ease of obtaining fish. The availability of fish in urban areas may differ with the availability of fish in rural areas that may affect the purchase of fish in families. The availability of fish in the region and where to get fish is also a factor that influences the mother to buy fish. People living in urban areas with high fish resources will be different in the amount of money they spent to buy the fish with people living in rural areas with little fish resources. Based on the exposure, this study aims to : 1) compare perceptions, attitudes, and buying behaviour of fish in rural and urban families; 2) analyze the influence of perception and attitude toward buying behaviour of fish in rural and urban families.

\section{Method}

This research used cross-sectional study design. The research location was chosen purposively, in Kelurahan Kandang, Panjang, Pekalongan City and Duwet Village, Pekalongan Regency. The study was conducted from February to March 2017. The population in this study were mothers who lived in Kandang Panjang and Duwet Village. The sample of this research is mother who were elected and willing to become respondent. The reason for choosing the mother as the respondent because of mother is a decider of food in the family. Sampling technique used quota sampling method.

The data collected in this research was primary data. Primary data obtained through interviews using questionnaires include: (1) individual and family characteristics including age, length of education, type of work, family size, and family income; (2) perception are measured by instrument modified by Waysima (2011). Perception instrument consists of 15 points of statement with three parts, namely the availability of fish, fish prices, and ease of fish processing; (3) The attitude consists of three parts, namely cognitive, affective, and conative based on the development of Engel et al., (1995) attitude theory consisting of 17 points of the statement. Each statement of perception and attitude using fourpoints Likert scale ( $1=$ strongly disagree, $2=$ disagree, $3=$ agree, $4=$ strongly agree); (4) Purchasing behavior was measured by purchase location, type of fish purchased, the frequency of purchase, fish price, and expenditure for fish.

The data processed and analyzed using Microsoft Excel and Statistical Package for Social Science (SPSS). Total score from the variable of perception and attitude then transformed into index score. The index scores grouped into three categories namely low (<33.33), moderate (33.33-66.66), and high (> 66.66).

Data analysis in this research used descriptive analysis to identify each variable. Pearson correlation test to know the relationship between variables, different test by using independent sample t-test to analyze the difference of each variable. Regression test used to analyze the influence of individual characteristics, family characteristics, perception, attitude, and location towards types of fish purchasing behaviour. The regression test was divided into two models; the first model was to analyze the influence of individual characteristics, 
family characteristics, perceptions, attitudes, and location toward the type of fish purchased by using logistic regression test. The second model is to analyze the influence of individual characteristics, family characteristics, perceptions, attitudes, and location toward expenditure for fish.

\section{Result}

\section{Individual and Family Characteristics}

Different test results show that between rural and urban areas there was a significant difference in all variables except in family size indicating that there was no significant difference between rural and urban. The mean of age of rural mothers is younger (41.68) than urban mothers (45.56). The average of length of education for mothers were five years higher in urban areas (12.10) than in rural (7.08). The average of income per capita in urban families was higher ( $\mathrm{Rp}$ $1,265,712)$ than in rural families ( $R p$ 493,844). Mother's job in both areas almost a half mother has status as a housewife or unemployee $(47,0 \%)$. A total of 62.0 percent of mothers in rural areas are housewives or unemployed, and 20 percent of mothers in rural areas work as labourers. The largest percentage of mother's job in the urban area is a housewife or unemployed mother $(32,0 \%)$ then as much as $24,0 \%$ mother work as a trader.

\section{Mother's perception toward fish}

Perception of fish is divided into three parts, namely the availability of fish in the region, prices of fish, and easiness of processing fish. The availability of fish in urban areas more than rural ares, types of fish consist of sea fish and freshwater fish. Mothers in rural areas more easily obtain freshwater fish species such as catfish, pomfret, carp and fish that have been processed such as salted fish, pindang fish and grilled fish. The average value indicates that fish prices in urban area are more varied than in rural areas, but fish prices in both areas are still affordable. The easiest way to process fish by mother in both areas is frying the fish. Roasting and burning fish is considered quite complicated by the mother because of the unavailability of tools to roast and burn fish. Making fish into curry is also considered difficult by the mother because it requires a lot of material and takes a long time to cook it.

Different test results showed a significant difference between mother perception to fish in the rural and urban area $(p=0.001)$. Mother's perception of fish was higher in the urban area compared with the rural area, with an average value of 63.47 in urban and 59.11 in the rural area. Differences in mother's perception of fish are influenced by the availability of fish, price of fish, and easiness of processing fish. The perception of fish in both regions equally has the largest percentage in the medium category. In rural areas, most mothers (84\%) have a medium perception of fish. In urban area, $44 \%$ of mothers have a high perception of fish; the percentage is higher than in rural areas (16\%) (Table 1). 
Table 1 Distribution of mothers by perception of fish category and region

\begin{tabular}{lcccccc}
\hline \multirow{2}{*}{ Category of perception } & \multicolumn{2}{c}{ Rural } & \multicolumn{2}{c}{ Urban } & \multicolumn{2}{c}{ Total } \\
\cline { 2 - 7 } & $\mathrm{n}$ & $\%$ & $\mathrm{n}$ & $\%$ & $\mathrm{n}$ & $\%$ \\
\hline Low $(<33.3)$ & 0 & 0.0 & 0 & 0.0 & 0 & 0.0 \\
Medium $(33.3-66.6)$ & 42 & 84.0 & 28 & 56.0 & 70 & 70.0 \\
High $(>66.6)$ & 8 & 16.0 & 22 & 44.0 & 30 & 30.0 \\
\hline Total & 50 & 100.0 & 50 & 100.0 & 100 & 100.0 \\
\hline
\end{tabular}

\section{Mother's attitude toward fish}

Statement of attitude is divided into three parts, namely cognitive, affective, and conative. Mothers in urban areas have higher cognitive attitudes than mothers in rural areas. Mother's affective attitudes toward fish are medium. Various types of fish are available in urban, and mother education causes knowledge of fish to be better. The mother's conative attitude in both regions is medium. Both mothers in urban and rural areas will choose other types of food such as eggs, tempeh, and know when family finances are bad. Overall, the attitude of mothers in both areas towards the fish is in the medium category. Seen from the number of mothers who entered the category as much as $77 \%$. Based on the results of t-test showed that overall attitude toward fish, there is a significant difference between rural and urban $(p=0,001)$. Viewed from the average score of the two regions, urban areas have a higher average (63.37) than rural areas (58.86), with minimum and maximum values in both regions of 47-78. Mother's attitude to fish between rural and urban areas is different because mothers in urban areas prefer fish compared to other animal protein, urban mother knowledge about fish is also better than mothers in rural areas (Table 2).

Table 2 Categories of mother attitudes toward fish and territory

\begin{tabular}{lcccccc}
\hline \multirow{2}{*}{ Attitude category } & \multicolumn{2}{c}{ Rural } & \multicolumn{2}{c}{ Urban } & \multicolumn{2}{c}{ Total } \\
\cline { 2 - 7 } & $\mathrm{n}$ & $\%$ & $\mathrm{n}$ & $\%$ & $\mathrm{n}$ & $\%$ \\
\hline Low $(<33.3)$ & 0 & 0.0 & 0 & 0.0 & 0 & 0.0 \\
Medium $(33.3-66.6)$ & 42 & 84.0 & 35 & 70.0 & 77 & 77.0 \\
High $(>66.6)$ & 8 & 16.0 & 15 & 30.0 & 23 & 23.0 \\
\hline Total & 50 & 100.0 & 50 & 100.0 & 100 & 100.0 \\
\hline
\end{tabular}

\section{Fish Purchasing Behavior}

Mothers in urban areas prefer to buy fresh fish compared to processed fish. In contrast, mothers in rural areas prefer to buy processed fish, as much as $54 \%$ of mothers choose to buy processed fish (baked/ pindang). This is caused by mothers in rural areas as much as $72 \%$ more often buy fish at stalls near home rather than buying in the market. Besides, the price of processed fish is very cheap that is only around Rp 5.500 - Rp6.000. Unlike mothers in rural areas, mothers in urban areas often buy fish in the market (50\%) and pitchmans (46\%) rather than buying fish in stalls.

The average frequency of fish purchasing in rural areas is higher than in urban areas. Viewed from both areas, the frequency of fish purchasing per week is more than half in the medium category that is as much as $54 \%$. As many as $54 \%$ 
of mothers in rural areas spend money to buy fish in the category of $\leq \mathrm{Rp} 100,000$ per month. While mothers in urban areas spend more money to buy fish in the category of Rp 100.001 - Rp 300.000 per month. This shows that mothers in urban areas spend more money to buy fish. This is because mothers in urban areas prefer to buy fresh fish that are more expensive than processed fish. Different test results indicate that there are significant differences in fish expenditure between rural and urban $(\mathrm{p}=0.000)$ (Table 3$)$.

Table 3 Distribution of location, type of fish, frequency of purchase and expenditure for fish by region

\begin{tabular}{|c|c|c|c|c|c|c|}
\hline \multirow{2}{*}{ Fish Purchase Behavior } & \multicolumn{2}{|c|}{ Rural } & \multicolumn{2}{|c|}{ Urban } & \multicolumn{2}{|c|}{ Total } \\
\hline & $\mathrm{n}$ & $\%$ & $\mathrm{n}$ & $\%$ & $\mathrm{n}$ & $\%$ \\
\hline \multicolumn{7}{|l|}{ Fish purchase location } \\
\hline Market & 8 & 16.0 & 25 & 50.0 & 33 & 33.0 \\
\hline Pitchman & 6 & 12.0 & 23 & 46.0 & 29 & 29.0 \\
\hline Stalls & 36 & 72.0 & 2 & 4.0 & 38 & 38.0 \\
\hline Total & 50 & 100.0 & 50 & 100.0 & 100 & 100.0 \\
\hline \multicolumn{7}{|l|}{ Type of fish purchased } \\
\hline Fresh sea fish & 6 & 12.0 & 35 & 70.0 & 41 & 41.0 \\
\hline Fresh freshwater fish & 17 & 34.0 & 11 & 22.0 & 28 & 28.0 \\
\hline Processed fish & 27 & 54.0 & 4 & 8.0 & 31 & 31.0 \\
\hline Total & 50 & 100.0 & 50 & 100.0 & 100 & 100.0 \\
\hline \multicolumn{7}{|c|}{ Frequency of purchase per week } \\
\hline Less $(\leq 2)$ & 19 & 38.0 & 17 & 34.0 & 36 & 36.0 \\
\hline Medium (3-4) & 23 & 46.0 & 31 & 62.0 & 54 & 54.0 \\
\hline High (5-7) & 8 & 16.0 & 2 & 4.0 & 10 & 10.0 \\
\hline Total & 50 & 100 & 50 & 100 & 100 & 100 \\
\hline Rataan & \multicolumn{2}{|c|}{3.08} & 2.88 & & \multicolumn{2}{|c|}{2.98} \\
\hline \multicolumn{7}{|c|}{ Fish expenditure per month (Rp) } \\
\hline$\leq 100.000$ & 27 & 54.0 & 7 & 14.0 & 34 & 34.0 \\
\hline 100.001-300.000 & 21 & 42.0 & 35 & 70.0 & 56 & 56.0 \\
\hline$>300.000$ & 2 & 4.0 & 8 & 16,0 & 10 & 10.0 \\
\hline Total & 50 & 100 & 50 & 100 & 100 & 100 \\
\hline Mean & \multicolumn{2}{|c|}{123960} & \multicolumn{2}{|c|}{228080} & \multicolumn{2}{|c|}{176020} \\
\hline
\end{tabular}

The Influence of Mother Characteristics, Family Characteristics, Perceptions and Attitudes toward Fish Purchase Behavior

\section{Model 1 : Influence on Fish Type}

The logistic regression test is used to see the influence of age, family size, family income, perception, attitude, a status of mother work, and location toward a type of fish purchasing. Based on the results of logistic regression test showed that the location has a significant effect on the type of fish purchased with a value of $\mathrm{B}$ of 2.229. This indicates that mothers in urban areas are more likely to buy fresh fish than mothers in rural areas. Perceptions and attitudes have no significant effect on the type of fish purchasing. The value of Negelkerke R square shows 
that the model only describes $33.4 \%$. The influence of variables studied on the type of fish purchased. The rest $(66.6 \%)$ is influenced by the variable not studied (Table 4).

Table 4 Regression coefficients of individual characteristics, family characteristics, perceptions, and attitudes toward the type of fish purchased $(0=$ processed fish, 1 = fresh fish)

\begin{tabular}{lccc}
\hline \multicolumn{1}{c}{ Variable } & B & Exp (B) & Sig. \\
\hline Constants & -1.236 & & 0.693 \\
Mother age (year) & -0.008 & 0.992 & 0.781 \\
Family size (people) & 0.186 & 1.204 & 0.303 \\
Family income (Rp000 / month) & 0.000 & 1.000 & 0.368 \\
Perception (index) & -0.003 & 0.997 & 0.942 \\
Attitude (index) & 0.010 & 1.010 & 0.800 \\
Work mother (0 = not working; $1=$ & 0.104 & 1.109 & 0.848 \\
work) & 2.229 & 9.291 & $0.002^{* *}$ \\
Locations (0 = rural; 1 = urban) & & 0.334 & \\
\hline Negelkerke R square & & $0.000^{* *}$ & \\
Sig. & & &
\end{tabular}

\section{Model 2 : Influence on Expenditure on Fish}

Multiple linear regression tests is used to see the effect of age, family size, family income, perception, attitude, a status of mother work and location to expenditure for fish. Mother's education variable is not included in the model because it has a very close relationship with the location and income of the family. Based on the results of multiple linear regression test in Table 5 shows that perception and location have a significant positive effect on expenditure for fish per month with a B value of 4.034 for perception and 77.963 for location. This means that each increment of a perceptual score will increase fish expenditure by 4.034 points. This also means that mothers in urban areas have the opportunity to buy fish 77.963 times higher than mothers in rural areas. In addition, the results showed that mother's age significantly negative effect on expenditure for fish per month with a value of B -2.312 means that the increasing age of the mother will reduce the expenditure of fish of $\mathrm{Rp} 2.312$. The Adjusted $\mathrm{R}$ Square value indicates that the model only explains the $24.8 \%$ of the variables that affect the expenditure on the fish, i.e., individual characteristics, family characteristics, perceptions, attitudes and the remain (75.2\%) influenced by unresearched variables (Table 5).

Table 5 Regression coefficients of individual characteristics, family characteristics, perceptions, attitudes, and areas of expenditure for fish per month

\begin{tabular}{lccc}
\hline \multicolumn{1}{c}{ Variable } & $\begin{array}{c}\text { Unstandardized } \\
\text { coefficients }\end{array}$ & $\begin{array}{c}\text { Standardized } \\
\text { coefficients }\end{array}$ & Sig. \\
\hline Constants & -152.086 & & 0.257 \\
Mother age (year) & -2.312 & -0.183 & $0.026^{*}$ \\
Family size (people) & 2.666 & 0.032 & 0.786
\end{tabular}




\begin{tabular}{lccc}
\hline & & & \\
Family income (Rp000 / month) & 0.002 & 0.041 & 0.447 \\
Perception (index) & 4.034 & 0.229 & $0.007^{* *}$ \\
Attitude (index) & 1.906 & 0.112 & 0.465 \\
Work mother (0 = not working, 1 & 16.622 & 0.069 & 0.385 \\
work) & 77.963 & 0.323 & $0.005^{* *}$ \\
Locations (0 = rural, 1 = urban) & & 5.660 & \\
\hline F & & 0.248 & \\
Adjusted R square & $0.000^{* *}$ & \\
Sig. & & \\
\hline
\end{tabular}

*) significant on $p$-value $<0,05 * *)$ significant on $p$-value $<0,01$

\section{Discussion}

The results show that mothers in larger urban areas spend money to buy fish. This is following the research of Ruwani et al., (2014) that urban consumer types have higher purchasing behaviour than rural consumer types. The amount of money spent on buying fish depends on the type of fish selected, the number of fish purchasing, the price, and the frequency of buying fish in a month. It can also be caused by mothers in urban areas prefer to buy fresh fish compared to fish such as catfish, cobs, kites that cost more than fish that have been processed such as pindang and bake.

Purchase location that is often visited by mother in the rural area is warung.Warung chosen mother in the rural area because close to the residence. This is in line with research Jha (2013) which stated that rural communities prefer to make purchases in places close to home like a stall. While mothers in urban areas buy more fish in the market and street vendors. This is because in the market there are more types of fish available and fish sold by street vendors have good quality. Suryawati et al., (2016) stated that the reason someone chooses shopping at a pitchman because of the speed of service and easeiness of access.

Logistic regression test results (first model) showed that the location had a significant positive effect. However, the perception and attitude in the first model have no significant effect. The result of multiple linear regression tests (second model) mentioned that mother's perception and geographical location have a significant positive effect to expenditure for fish, while mother's age had a significant negative effect on the fish purchase. But the attitude has no significant effect on the expenditure for fish.

Mother's age had a significant negative effect on spending money to buy fish. This means that the increasing age of mother then lowers the money spent to buy fish. When viewed on the results of the correlation test between the mother's age with education states that the younger the mother's age, the higher the mother's education. Mother's education is high then the mother's knowledge about the benefits of fish is also high so that money spent to buy fish is greater. Consumers who have education will be more responsive to information (Sumarwan, 2011). This is in line with the results of research Ruwani et al. (2014) the age and duration of mother's education affect food purchasing behaviour.

The results showed that perception has a significant positive effect on fish expenditure. This indicates that mothers in rural and urban areas in buying fish are influenced by the perception of fish availability in the region, price, and easiness 
in processing fish. This is in line with research Somantri (2014) that perceptions affect the buying behaviour. While the perception does not significantly affect the type of fish purchased. This suggests that the mother's perception of the fish does not affect the type of fish that the mother will buy. Constraints that usually prevent a person from eating fish as a determinant of food in the family is the perception about the difficulty of buying, weeding, and processing and price (Waysima, 2011).

The results showed that the attitude did not significantly influence the buying behaviour. This is in line with the results of research Anggiasari et al. (2013) which indicates that consumer attitudes have no significant effect on the buying behaviour of local and imported fruits. However, this is not in line with Retnaningsih et al. (2010) and Idaman et al. (2012). This happens because the fish is not a staple food for people in the area.

According to Sumarwan (2011), the residence of a consumer will affect his consumption patterns. Consumers who live in the village have limited access to products and services, while consumers in the city are easier to obtain the necessary goods and services. The location is very influential on the buying behaviour of fish both in the first model and the second model; this is in line with the results of research Kamila (2016) that the geographical location affects the buying behaviour. Urban area there are more types of fish ranging from processed fish such as pindang and bake to fresh fish both fresh sea fish and fresh water fish.

Limitations in this study were the selection of research sites using the purposive sampling, the location of the study used only one location in rural and one urban location, this study only saw the expenditure for fish only and the weight of the fish was not measured in this study. In addition, between problems with solutions to increase fish consumption is still lacking.

\section{Conclusion and Recommendation}

\section{Conclusion}

Mother's perception and attitude towards fish as a whole are higher in urban than rural. Perceptions about the easiness of processing fish there are significant differences, but the availability and price of fish are not found the real difference between rural and urban. Mother cognitive attitudes are higher in urban than in rural areas. Affective attitudes and conative attitudes are not significantly different between rural and urban. The behaviour of fish purchases in rural and urban areas differed significantly in spending on fish. Mothers in urban areas spend more money to buy fish. The result of multiple linear regression tests showed that mother's age, perception and location had a significant effect on buying behaviour of fish. The results of mother's logistic regression tests in urban areas have a greater opportunity to buy fresh fish than processed fish.

\section{Recommendation}

Based on the results of research, suggestions that can be given by the writer that considering enough fish bought by mother, hence the availability of fish in the region need to get attention especially by local government so that mother can buy fish with various type. There are still many mothers who do not 
know the nutritional content and the benefits of fish it is necessary to be socialized or counselling about the nutritional content and the benefits of fish for health. Further research is advised to choose some locations that represent rural and urban areas and should expenditure other than fish, and non-food expenditure also measured in this research. In addition, other variables such as knowledge and preference for fish can be added.

\section{References}

Alibabic, V., Jokic, S., Mujic, I, Rudic, D., Baaajramovic, M, Jukic, H. (2011). Attitudes, behaviours, and perception of consumers' from northwestern Bosnia and Herzegovina toward food products on the market. Procedia Social and behaviour sciences, 15(2011), 2932-2937

Anggiasari, P., Yuliati, L. N., Retnaningsih. (2013). Pengaruh ethnocentrism terhadap sikap, preference, dan perilaku pembelian buah lokal dan impor. Jurnal manajemen \& Agribisnis, 10(2), 128-136.

Badr, L. M. (2015). Perceiver barriers to consumption freshwater fish in Morocco. British Food Journal, 117(1), 2711-285.

Jafaar, S. N., Lalp, P. E., Mohamed, M.( 2012). Consumer's perceptions, attitudes and purchase intention towards private label food products in Malaysia. Journal of Bussiness and Management Science. 2(8),73-90.

Idaman N, Yuliati LN, Retnaningsih. 2012. Sikap konsumen terhadap beras organik. Jurnal Manajemen \& Agribisnis. 9(2): 121

Indriana, J., Widajanti, L. (2005). Hubungan pendapatan, pengetahuan gizi ibu, dengan ketersediaan ikan tingkat rumah tangga daerah perkotaan. Jurnl Giz. Indonesia, 1(1)

Jannah, K. M. (2015, March 28). Konsumsi ikan RI kalah jauh dengan Malaysia dan Jepang. Okezone Finance. Retrieved from https://economy.okezone.com/read/2015/03/27/320/1125265/konsumsiikan-ri-kalah-jauh-dari-malaysia-jepang

Jha, M. (2013). A study on the rural consumer buying behavior in Bihar. Int Jour of Marketing, Finansial Services \& Management Research, 2(2), 176.

Kamila, N., W. (2016). Pengaruh sikap terhadap perilaku pembelian produk kemasan plastik dan pengelolaan sampah rumah tangga di perdesaan dan perkotaan (skrips). Institut Pertanian Bogor, Bogor, Indonesia.

Khaniwale M. (2015). Consumer buying behavior. Journal of Innovation and Scientific Research, 14(2),278-286.

Masoom, M., Pasha, S., Rahman, S. (2015). Factorss affecting the consumer purchasing decisions of perishable food: eksploring the attitudes and the preferences. Management dynamic in the Knowledge economy, 3(3), 509531.

Nurjannah, Hidayat T, Perdana S. (2015). Analisis faktor-faktor yang memengaruhi konsumsi ikan pada wanita dewasa di Indonesia. JPHPI, 18(1), 19-27.

Retnaningsih, Utami, P., Muflikhati, I. (2010). Analisis faktor-faktor yang berpengaruh terhadap sikap dan perilaku membeli buku bajakan pada mahasiswa IPB. Jur.Ilm.Kel.\& Kons, 3(1),82-88 
Ruwani, A., Retnaningsih, Simanjuntak, M. 2014. Nilai tipe konsumen rumah tangga dan kaitannya dengan perilaku pembelian produk makanan kemasan. Jur.Ilm.Kel.\& Kons.7(1):48-57

Sangkumchaliang, P., Huang, W.C. (2012). Consumers perception and attitudes of organic food products in Northen Thailand. Internal Food and Agribusiness Management Riview, 15(1)

Somantri, R. F. (2014). Pengaruh persepsi dan pengetahuan terhadap perilaku pembelian perhiasan emas pada keluarga petani (Skripsi). Institut Pertanian Bogor, Bogor, Indonesia.

Sumarwan, U. (2011). Perilaku Konsumen: Teori dan Penerapannya dalam Pemasaran. Indonesia, Bogor: Ghalia Indonesia

Simanjuntak, M., Yurita. (2012). Persepsi dan preferensi iklan memengaruhi niat beli pada produk makanan ringan. Jur. Ilm. Kel. \& Kons, 5(2), 185-192.

Suryawati, S.H., Saptanto, S., Putri, H. M. (2016). Analisis preferensi konsumsi ikan menghadapi natal 2015 dan tahun baaru 2016. J. Kebijakan Sosek KP, 6(1), 15-24.

Verbeke, W., Vackier, I. (2004). Individual determinants of fish consumption: application of the theory of planned behavior. Appetite, 44(2005), 67-82.

Waysima. (2011). Pengaruh ibu pada perilaku makan ikan laut siswa sekolah dasar di Kabupeten Jepara dan Kabupaten Grobogan, Jawa Tengah (Disertasi). Institut Pertanian Bogor, Bogor, Indonesia.

Sumarwan, U., Khomsan, A., Zakaria, F. (2011). Persepsi dan sikap afektif mempengaruhi perilaku ibu menyediakan ikan laut dalam menu keluarga. Jur.Ilm.Kel.\&Kons, 4(1),74-81 